\title{
The Role of Supervisors in the Hygiene Practice Compliance of the Food Sector Workers
}

\author{
Senay Yürür ${ }^{1, *}$, and Tugba Aktar² \\ ${ }^{1}$ Department of Management, Faculty of Economics and Administrative Sciences, Yalova University, Yalova, Turkey \\ ${ }^{2}$ Alanya Alaaddin Keykubat University, Food Engineering Department, 07425, Antalya, Turkey
}

\begin{abstract}
Food hygiene is indisputably one of the most important issues in terms of public health and safety. Food workers are the leading staff members for the compliance of the basic hygiene rules. COVID19 pandemic has attracted more attention especially for the exported goods from the higher case countries. Even though there is no evidence about the food contamination and COVID-19 risk, according to the European Food Safety Authority, food hygiene practices are important to avoid any contamination risks. Managers are known to have a significant influence on the behavior of their subordinates. In the relevant literature, it is stated that "interactional justice", which is called the behavior of managers concerning their subordinates and providing adequate information and explanation about the decisions taken, is the most important indicator of the performance and efficiency of subordinates. From this point on, it is thought that interactional justice will affect the behavior of food workers to comply with the hygiene rules. In this research, employees' perceptions of interactional justice are planned to be measured using the informational and interpersonal justice subscales of the organizational justice scale. The tendencies to comply with the hygiene rules will be measured by asking the requirements of the HACCP food security system. At the end of this study, we expect to reach the processing operation involved workers of the investigated food companies.
\end{abstract}

\section{Introduction}

Food hygiene is indisputably one of the most important issues in terms of public health and safety. Food workers are the leading staff members for the compliance of the basic hygiene rules. Food safety has always been an issue for public health concern. But with the recent COVID-19 pandemic has attracted more attention especially for the exported goods from the higher case countries. Even though there is no evidence about the food contamination and COVID-19 risk, according to the European Food Safety Authority, food hygiene practices are important to avoid any contamination risks [1]. According to the literature, many countries including Turkey has inadequate hygiene levels of food workers [2-5]. The question that comes to mind at this point is, what does the hygiene behavior of employees depend on? Are the company rules, procedures, or measures, sufficient for the employees to comply with these rules? Or will the behavior of managers towards employees cause them to abide by or knowingly violate these rules? For this, it is planned to survey food business employees.

\section{Literature Review}

Food hygiene, which is an undeniable issue in terms of public health and safety, needs to be researched in every aspect. Systems aiming to guarantee food safety such as
HACCP are getting more and more attention day by day [6]. However, the fact that food businesses have advanced food safety systems such as HACCP or have hygiene rules defined in detail for their employees to comply cannot guarantee that these rules will be followed. Employee behaviors are phenomena that are extremely complex and affected by many individual or organizational factors. For this reason, the attitudes and behaviors of employees in food businesses and especially in production, which are critical in terms of food safety, should be investigated in all aspects.

Managers are known to have a significant influence on the behavior of their subordinates [7]. In the relevant literature, it is stated that "interactional justice" [8], which is called the behavior of managers concerning their subordinates and providing adequate information and explanation about the decisions taken, is the most important indicator of the performance and efficiency of subordinates [9-11]. Because feelings such as trust and loyalty developed between managers who treat their subordinates fairly and their subordinates cause employees to perform higher [12]. Interactional justice consists of two dimensions: managers' giving sufficient information to their subordinates about the decisions/processes and treating them with kindness and respect. The first of these is called informational justice and the other is called interpersonal justice [13].

\footnotetext{
* Corresponding author: tugba.aktar@,alanya.edu.tr
} 
Justice within the organization is also one of the main determinants of employees' voluntary compliance with the rules [12]. Employees who believe that they are treated fairly tend to follow the rules set by the organization more. Moreover, organizational justice causes employees to do more than they are expected of them $[10,14-16]$. On the other hand, it is reported that injustice creates a tendency for employees to harm their organizations (eg, theft, [17]).

From this point on, it is thought that interactional justice will affect the behavior of food workers to comply with the hygiene rules. Based on the abovementioned research results, food workers who perceive their managers as fair can be expected to comply with the hygiene rules voluntarily. On the contrary, we can expect employees who perceive their manager as unfair to violate hygiene rules - perhaps knowingly and willingly, to harm the organization and its manager. Based on this, the research model and the hypotheses of this research can be expressed as follows:

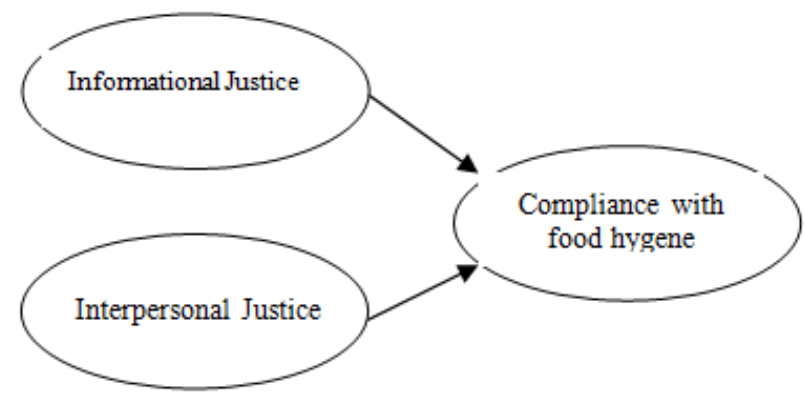

Research Model

Fig. 1.

H1. Employees who perceive their managers fairly have a high level of compliance with food hygiene rules.

H2. Employees who perceive their managers unfairly have a high level of violation of food hygiene rules.

\section{Method}

Empirical research will be conducted to test the above hypotheses. For this purpose, two-step verification steps are planned. The first research will be quantitative research and data will be collected by survey method. In this research, employees' perceptions of interactional justice and their tendency to comply with hygiene rules will be measured using the informational and interpersonal justice subscales of the organizational justice scale developed by Colquitt [12]. The tendencies to comply with the hygiene rules will be measured by asking the requirements of the HACCP food security system. At the end of the recent study, it is aimed to reach the processing operation involved workers of the investigated food companies.

The data obtained will be evaluated in the SPSS package program, and the effect of the interactional justice perceptions of employees to their organizations on the level of compliance with the rules regarding food safety will be measured by using correlation and multiple regression analyses.

In the second stage of the study, it is planned to question and verify the main reasons for the results obtained in the initial study. Interviews are planned with 20 employees who will be selected according to the random sampling method among the respondents reached in the first stage. Hence, this research will examine to illustrate the outcome of the supervisors' behavior to comply with food hygiene rules. As a result, the findings obtained from this research will draw attention to the role of managers in compliance with hygiene rules in food businesses.

\section{Expected Results}

The present study is ongoing research and the data collection process is still ongoing. This ongoing study will be presented at the congress and it is planned to develop the model and method of the research as a result of the feedback received from our colleagues. Since sufficient data has not been collected for analysis so far, the expected results are included here.

Using the data obtained in the first phase of the study, it is expected to determine to what extent the fair or unfair behaviors of the managers of the food sector employees are effective in obeying the hygiene rules or violating these rules. If both hypotheses of the research are accepted, this result will be evidence of how important actors are managers for food hygiene in food production establishments. In this case, the effectiveness of written rules, regulations, or procedures that food businesses have to provide hygiene will become questionable. It can be concluded that it is not enough for a food business to have internationally recognized hygiene standards. The meaning of this result for food businesses may be that managers reconsider their roles and especially the production unit managers' behavior towards employees. For this process of regulating behavior and revising roles, it may be suggested to be more careful in the selection and appointment of managers in food businesses or to provide leadership training and behavioral training to managers in addition to technical training.

As a result of the research, it will also be determined which dimension of interactional justice is more effective on the behavior of complying with hygiene rules. In other words, it will be determined whether the information-based behavior of the managers is fair or gentle towards the employees, which affects the compliance of the employees more to the hygiene rules. Collectivist and high power distance culture for Turkey, showing properties [18], interpersonal justice's informational justice on the size of the obedience to the rules of hygiene can be expected to have a more powerful effect. So individuals working in Turkey may prefer their managers to behave kind and fair instead of being able to provide adequate information about the process and business. However, informational justice is more important for the behavior to comply with the rules of hygiene. For example, communicating all kinds of 
hygiene-related information to employees should increase the level of compliance with these rules. However, as stated above, cultural differences may affect this result. Whether this cultural difference will emerge as a result of this research will be seen.

\section{References}

1. M. Muslu, D.Ö. Ersü, Yeni Koronavirüs (SARSCoV-2/COVID-19) Pandemisi Sirasinda Beslenme Tedavisi ve Önemi, Beslenme ve Diyet Derg, 48, 73-82 (2020)

2. F. Elmacioğlu, Ş. Dabak, C. Dündar, et all, Samsun İl Merkezindeki Lokanta Mutfaklarının Hijyen Durumunun Değerlendirilmesi, Beslenme ve Diyet Derg, 28, 54-58 (1999)

3. M. Baş, A.Ş. Ersun, G. Kıvanç, The evaluation of food hygiene knowledge, attitudes, and practices of food handlers' in food businesses in Turkey, Food Control, 17, 317-322 (2006)

4. P. Akbulut, Yalova ilinde faaliyet gösteren hazır yemek üretim yerlerinde çalışan personellin hijyen bilgi düzeyi ile üretilen yemeklerin mikrobiyolojik kalitesi arasındaki ilişkinin belirlenmesi (2010)

5. C.T. Aral, DALI GMA TEKİRAĞ NAMIK KEMAL ÜNIVERSITESI

6. Ö.C. Dölekoğlu, Tüketicilerin İşlenmiş Gıda Ürünlerinde Kalite Tercihleri, Sağlık Riskine Karşı Tutumları ve Besin Bileșimi Konusunda Bilgi Düzeyleri (Adana Örneği), Tarımsal Ekon Araştırma Enstitüsü, 105 (2003)

7. R.J. Bies, Interactional (in) justice: The sacred and the profane, Adv. Organ. justice, 89118 (2001)

8. R.J. Bies, The predicament of injustice: The management of moral outrage, Res. Organ Behav. (1987)

9. S. Williams, The effects of distributive and procedural justice on performance, J. Psychol., 133, 183-193 (1999)

10. S.S. Masterson, K. Lewis, B.M. Goldman, M.S. Taylor, Integrating justice and social exchange: The differing effects of fair procedures and treatment on work relationships, Acad. Manag. J., 43, 738-748 (2000)

11. R. Cropanzano, C.A. Prehar, P.Y. Chen, Using social exchange theory to distinguish procedural from interactional justice, Gr. Organ Manag., 27, 324-351 (2002)

12. J.A. Colquitt, On the dimensionality of organizational justice: a construct validation of a measure, J. Appl. Psychol., 86, 386 (2001)

13. J. Greenberg, The social side of fairness: Interpersonal and informational classes of organizational justice, In: Cropanzano R (ed) Justice in the Workplace: Approaching Fairness in Human Resource Management (Lawrence Erlbaum Associates Publishers, New Jersey, 1993)

14. R.H. Moorman, Relationship between organizational justice and organizational citizenship behaviors: Do fairness perceptions influence employee citizenship?, J. Appl. Psychol., 76, 845 (1991)

15. R.H. Moorman, G.L. Blakely, B.P. Niehoff, Does perceived organizational support mediate the relationship between procedural justice and organizational citizenship behavior?, Acad. Manag. J., 41, 351-357 (1998)

16. C. Viswesvaran, D.S. Ones, Examining the construct of organizational justice: A metaanalytic evaluation of relations with work attitudes and behaviors, J. Bus. Ethics., 38, 193203 (2002)

17. J. Greenberg, Employee theft as a reaction to underpayment inequity: The hidden cost of pay cuts, J. Appl. Psychol., 75, 561 (1990)

18. G. Hofstede, Culture's consequences: International differences in work-related values sage (1984). 